\title{
Ege Adaları Tartışması ve Türkiye: II. Dünya Savaşı Süreci
}

DOI: $10.26466 /$ opus.568459

\author{
Yaşar Semiz* -Güngör Toplu** \\ *Prof. Dr., Selçuk Üniversitesi, Sosyal Bilimler Meslek Yüksekokulu, Selçuklu/ Konya/ Türkiye \\ E-Posta: ysemiz08@gmail.com \\ ORCID: 0000-0002-9204-8014 \\ **Öğr. Gör., Selçuk Üniversitesi, Atatürk İlkeleri ve İnkılâp Tarihi Böl., Selçuklu/ Konya/ Türkiye \\ E-Posta: gtoplu@selcuk.edu.tr \\ ORCID: $\underline{0000-0002-0511-3528}$
}

\section{Öz}

Ege adaları konusu 1912'de, İtalya ile Osmanlı Devleti arasındaki Trablusgarp Savaşı sırasında Rodos ve On iki Ada'nın İtalyanlar tarafindan işgali ile gündeme geldi. Balkan Savaşı sırasında bazı adaların Yunanistan tarafindan işgal edilmesi ile devam etti. 24 Temmuz 1923 tarihli Lozan Antlaşması'nın 12. maddesi ile Gökçeada ve Bozcaada dışında kalan Ege Adaları'nı askerden arındırılmak şartıyla Yunanistan'a, 15. maddesi ile de Rodos ve On iki Ada'nın İtalya'ya bırakılması ile kısmen çözüme kavuşturuldu.Adalarla ilgili tartışma 4 Ocak 1932'de Türkiye ile Ittalya arasında yeniden gündeme geldi. Dr. Tevfik Rüştü Bey ile İtalyan elçisi Pompa Alisi arasında Ankara'da imzalanan antlaşma ile Bodrum Körfezi'ndeki Kara Ada ve Meis'e bağlı otuz adacıktan 19'u Türkiye'ye; 11'i ise İtalya'nın hâkimiyetinde bırakıldı. Ancak 1936 yılında İtalya'nın Laros adasını tahkim etmesi iki ülke arasındaki gerginliği yeniden arttırdı. II. Dünya Savaş sırasında adalardan Taşoz, Semadirek, Limni, Midilli ve Sakız'ın Almanlar tarafından işgal edilmesi ve Girit Adası'na da Mayıs 1941'de Alman paraşütçü birliklerinin indirilmesi ile konu yeniden tartışılmaya başlandı. Savaşı boyunca Almanya, elindeki adaları kendi saflarında savaşa girmek şartıyla Türkiye'ye vermek için zemin yokladı. Nisan 1941'de yapılan görüşmelerde Türkiye öneriyi kabul etmeye hazır görünüyordu fakat savaşın sonlarına doğru Türkiye'nin müttefiklerin safında savaşa girmeye hazırlandı̆̆ı sırada Doğu Ege adalarının Türkiye'ye devredilmesi önerisine sıcak bakılmadı. Türkiye, savaşın sonlarına doğru Sovyet tehdidi artmaya başlaması ile adalarla ilgili beklentilerinden tümü ile vazgeçerek $A B D$ ve İngiltere ile yakınlaşmaya arayışına girdi. Savaşın sonunda, savaşan taraflardan birisi olmadığı görüşünden hareketle adaların Yunanistan'a bırakıldı̆̆g Paris görüşmelerine de katılmadı.

AnahtarKelimeler: Türkiye, Yunanistan, Ege Adaları, Paris Antlaşması, Göç 


\title{
Aegean Islands Dispute and Turkey: World War II Period
}

\begin{abstract}
The issue of the Aegean Islands aro seuponinvasion of Dodecanese and Rhodes by the Italians during the Turco-ItalianWar between Italy and the Ottoman Empire in 1912. It continued with the occupation of certain islands by Greece during the Balkan Wars. This situation was partially resolved when the Aegean Islands, save for Gökçeada (Imbros) and Bozcaada (Tenedos), were given to Greece as per article 12 of the Treaty of Lausanne dated July 24, 1923, provided that they be demilitarized while Rhodes and Dodecanese were turned over to Italy as perarticle 15. The dispute flared once again between Turkey and Italy on 4 January 1932. According to the treaty signed by and between Dr. Tevfik Rüştü Bey and Italian Ambassador Pompeo Aloisi in Ankara; 19 out of 30 islets attached to Kara Ada and Megisti, islands located in the Gulf of Bodrum, were left to Turkey; while 11 fell under the rule of Italy. However, the tension between the two countries heightened once again after Italy's fortification of the island of Laros in 1936. The matter was reopened for discussion when the islands of Thasos, Samothrace, Lemnos, Lesbos, and Chios were occupied by the Germans during World War II and German paratroops landed on the island of Crete in May 1945. All throughout the war, Germany tried to see how the land lies by offering to give the islands to Turkey provided that she joined the war among German ranks. During negotiations carried out in April 1941, Turkey seemed ready to accept the proposal; but towards theend of the war, just as Turkey was prepared to participate on the side of the allied powers, they became ill-disposed towards turning over the Aegean Islands to Turkey. As the Soviet threat strengthened towards the end of the war, Turkey completely renounced its expectations regarding the islands and strived to draw closer with USA and England. At the end of the war, Turkey was not able to attend the Paris negotiations, where the islands were given over to Greece, with reference to the Notion that she was not among the parties to the war.
\end{abstract}

Keywords: Turkey, Greece, Aegean Islands, Paris Treaty, Migration 


\section{Giriş}

Ege adaları konusu 1912' de, İtalya ile Osmanlı Devleti arasındaki Trablusgarp Savaşı sırasında Rodos ve On iki Ada'nın İtalyanlar tarafından işgaliyle gündeme geldi ${ }^{1}$. Balkan Savaşı sırasında bazı adaların Yunanistan tarafından işgal edilmesi ile devam etti. 24 Temmuz 1923 tarihli Lozan Antlaşması'nın 12. maddesi ile Gökçeada ve Bozcaada dışında kalan Ege Adalarını askerden arındırılmak şartıyla Yunanistan'a, 15. ve 16. maddesi ile de Rodos ve On iki Ada'nın İtalya'ya bırakılması ile kısmen çözüme kavuşturuldu².

Adlarla ilgili tartışma 1927 'den itibaren yeniden başladı. Bu kez tartış1lan konu İtalya'ya bırakılan Rodos ve On iki Ada'nın etrafındaki kayalıklardı. İki ülke arasında yapılan görüşmelerde Meis'e tabi adacıklar konusunda bir mutabakata varılamıyordu. Türkiye, Lozan Antlaşması'nın 15. maddesinde Meis'e tabii adacıkların bahsedilmediği, bu yüzden konunun yine Lozan Antlaşması'nın 6. maddesinin ikinci fikrasındakinin aksine bir kayıt olmadığ takdirde karasuların 3 mil dâhilindeki ada ve adacıkların kara-sularına sahip ülkeye ait olacağı (Düstur, 1931, s.22- 23) tezinden hareketle kendisine bırakılması gerektiğini savunuyordu. İtalya ise Türkiye'nin aksine Lozan Antlaşmasi'nın 15. maddesindeki "bunların tevâbiinden olan adacıklar" ibaresinin Meis'i de kapsadığını iddia ediyordu. Taraflar arasında bir anlaşmaya varılamayacağı anlaşılınca Tevfik Rüştü Aras ve İtalyan Elçisi Orsini Barone arasında 30 Mayıs 1929'da imzalanan bir "tahkimnâme" (belge) ile konuyu Lahey Adalet Divanı'na götürmeye karar verdiler (Turan, 1965, s.115). Konu Haziran 1930'da Adalet Divanında görüşülmeye başlandı. Ancak bu süreçte de iki ülke arasındaki görüşmeler kesilmemişti. Taraflar arasında 4 Ocak 1932'de anlaşmaya varıldı. Dışişleri Bakanı Dr. Tevfik Rüştü Bey ile İtalyan Elçisi Pompa Alisi arasında Ankara'da imzalanan antlaşma ile Bodrum Körfezi'ndeki Kara Ada ve Meis'e bağlı otuz adacıktan 19' u Türkiye'ye; 11' i ise İtalya'nın hâkimiyetine bırakıldı. Anlaşma 14 Ocak 1933'te TBMM'de oylanarak

\footnotetext{
1- Rodos ve Onikiadanın italyanlar tarafından nasıl işgal edildiği konusunda (Kurtcephe, Ocak 1991, s.2) 'ye bakılabilir.

2 - Ilgili maddeler için bak. (Düstur, 1931, s.25- 27; Soysal, 1983, s.89- 92)
} 
kabul edildi ${ }^{3}$. Taraflar 3 Ocak 1933'te birer mektupla durumu Adalet Divanına da bildirmişlerdi ${ }^{4}$.

Bu çalışmada İkinci Dünya Savaşı sırasında Ege adaları sorunu iki başlık altında değerlendirilecektir. İlk kısımda Lozan'dan sonra Türkiye'nin adalara bakışı ele alınarak Almanların, Rusların ve İngilizlerin zaman zaman adaları neden Türkiye'ye bırakmak istedikleri, Türkiye'nin bu önerilere bakış açısı ve savaşın sonunda adaları işgal eden İngilizlerin buraları Yunanistan'a devretmesi konusu değerlendirilecektir. İkinci kısımda ise savaş yıllarında adalardan Türkiye'ye sığınan mülteciler konusu ele alınacaktır.

\section{Ege Adalarının Mülkiyeti Sorunu}

İtalya ile adalar konusunda varılan anlaşma 1933 'te TBMM'de oylanmasindan üç yıl sonra yeniden problemler yaşanmaya başlanmıştı. 1936 y1lından itibaren İtalya'nın adaları, özellikle de Laros adasını silahlandırmaya başlaması ile adalar konusunun yeniden gündeme gelmeye başlamıştı. Türkiye bu durun karşısında güvenliğini teminat altına almak için İngiltere ve Fransa ile yaptığı üçlü ittifak anlaşmasına "Bir Avrupa devleti tarafindan vaki olup Akdeniz mıntıkasında Türkiye'nin karışacağı bir savaşa müncer olan bir saldır hareketi halinde Fransa ve Ingiltere'nin Türkiye'ye her türlü desteği vereceği" maddesini koydurmuştu ${ }^{5}$.

15 Mart 1939'da Almanya'nun Çekoslovakya'yı, 7 Nisan 1939'da da İtalya'nın Arnavutluk'u işgal etmesi (Karabekir, 1995, s.28), Türkiye'yi, Mihver Devletlerin saldırganlığına karşı yeniden güvenlik arayışına yöneltti (Goloğlu, 1974, s.479). Bu süreçte Türkiye'nin birinci önceliği, her türlü baskıya rağmen savaşan devletlerarasında tarafsız kalmaktı (Wells,

\footnotetext{
3_ "26 Aralık 1932 tarihli Türkiye Cumhuriyeti ile italya Hükümeti arasında akdedilen itirafnamenin tasdiki hakkında 1/471 numaralı kanun lâyihası veHariciye ve Millî Müdafaa encümenleri mazbataları" sıra nu: 47; (TBMM ZabitCeridesi, 7-14 Ocak 1933, s.79- 80; Resmi Gazete 25 Ocak 1933, Sayı 2313).

4_ "26 Aralık 1932 tarihli Türkiye Cumhuriyeti ile italya Hükümeti arasında akdedilen itirafnamenin tasdiki hakkında 1/471 numaralı kanun lâyihası ve Hariciye ve Millî Müdafaa encümenleri mazbataları" sıra nu: 47; (TBMM ZabitCeridesi, 7-14 Ocak 1933, s. 79- 80) Sözleşme, 24 Mayıs 1933'te Milletler Cemiyeti Sekreterliği'ne 319 seri numarası ile tescil ettirilmişti (Denk, 1999, s.76; Turan, 1965, s.116).

5-Anlaşmanın birinci maddesinde "Türkiye'ye karşı bir Avrupa devleti tarafından vaki bir saldırı sonucunda Türkiye bu devletle muhasamata girdiği takdirde Fransa ve Birleşik Krallık Türk Hükümeti ile teşrikimesai edecekler ve ona yeddi iktidarlarında olan bütün müzahereti ifa eyleyeceklerdir" maddesivardı.
} 
Tarih yok, s. 170). Ancak o dönemin şartlarında tarafsızlık kolay yürütülebilecek bir politika değildi. Bu nedenle Türkiye, temel stratejisini "savaş dışı kalmak" olarak belirledi (Semiz-Akgün, 2007, s.241). Önce 12 Mayıs 1939 ' da İngiltere ile (TBMM Zabit Ceridesi, 12 Mayıs 1939, s.66- 68). Hatay meselesinin çözümünün ardından da Fransa ile (TBMM Zabit Ceridesi, 12 Mayıs 1939, s.69). "'Barış Cephesi" adı altında ortak bir deklarasyon yayımlad1 (Erden, 1999, s.214). ${ }^{7}$

Türkiye'nin, İtalya'nın kontrolündeki On iki ada ile ilgili kaygılarını İkinci Dünya Savaşı öncesi ve savaş yıllarında Almanya, İngiltere ve Rusya birçok kez dile getirdiler. Bu devletler, Türkiye'nin kendi saflarında savaşa girmesi durumunda adaları Türkiye' ye verebileceklerini ifade ettiler.

Almanya, Türkiye'nin İngiltere ile yakınlaşmasını önlemek için, 3 Mart 1941'de Romanya' dan geçerek Bulgaristan üzerinden Yunanistan'a inerek Balkanlarda yayılmasının ardından yaptığı açıklamalarda hiçbir şekilde Türkiye'ye saldırma niyetinde olmadığını ve mümkün olduğu kadar Türk hudutlarından uzak kalacağını belirtmişti (TBMM Zabit Ceridesi, 2 Ağustos 1944, s.5) $)^{8}$. Almanya'nın Ankara Büyükelçisi Von Papen bu doğrultuda 12Mayıs 1941'de Dışişleri Bakanı Şükrü Saraçoğlu ile14 Mayıs'ta da Cumhurbaşkanı İsmet İnönü ile görüşerek, 1 Mart 1941 tarihli Hitler' in iyi niyet mektubunu iletti ${ }^{9}$. Papen'in getirdiği mektupta Almanya, Türkiye'nin güvenliği ile ilgili endişe duyduğu konularda tam bir garanti vermekte, Yunan ve Bulgar topraklarında Almanya'nın aldığı tedbirlerin hiçbir şekilde Türkiye'nin toprak bütünlüğüne yönelik olmadığ 1

\footnotetext{
6- Burada Fransa ile de deklarasyon imzalanacağı ifade edilmektedir. (TBMM ZabitCeridesi, 12 Mayıs 1939, s.69).

7- Bu ittifaka göre; bir Avrupa devletinin saldırısı ile başlayan, Ingiltere ve Fransa'nın katılacakları bir savaş Akdeniz'e yayılırsa Türkiye, Ingiltere ve Fransa'ya yardım edecekti. Türkiye bir Avrupa devletininsaldırısına uğrarsa, Ingiltere ve Fransa kendisine yardım edecekti. Ancak Türkiye, antlaşmaya koydurduğu "Sovyet Çekincesi" de denen ek 2. Protokolle anlaşma hükümleri ile Kabul edilen yükümlülüklerinden doğan taahhütlerin kendisini Sovyetler Birliği ile bir savaşa sürüklemeyeceği konusunda güvence oluşturdu. (Koçak, 1986, s.270-274).

8- Şükrü Saraçoğlu bu önerinin arkasında "Bize bir âdem-i tecavüz misakının akdini teklif ettiler. Bu teklifi ve işin müteakip bütün safahatını müttefiklerimize haber vererek ve danışarak 18 Haziran 1941 tarihinde Alman- Türk muahedesini imzaladık. 18 Haziran 1941 tarihinde imzalanan muahedenin, esas şartı- başta Türk- Ingiliz ittifakı olmak Çizere- mevcut taahhütlerimizin mahfuz tutulmasıdır"(TBMM Zabit Ceridesi, 2 Ağustos 1944 s.5-6).

9. Hitlerin mektubu 1 Mart 1941 tarihini taşımakta ve Cumhurbaşkanı İsmet inönü'ye hitap etmektedir. (GizliBelgeler, 1968, s 137- 141; Barutçu, 1977, s.199).
} 
belirtilmekteydi (Gizli Belgeler, 1968, s 12-13, 133-134). Ayrıca bu konudaki iyi niyetlerinin bir ifadesi olarak Edirne'nin civarındaki arazinin ve Ege Denizi'nde Türk karasularına üç mil yakınında bulunan ve askerî yönden önemsiz kabul edilen iki adayı Türkiye'ye bırakılabileceğini belirtmişti (Gizli Belgeler, 1968, s.17) ${ }^{10}$.

Almanya, ABD'nin savaşa girmesinin ardından müttefiklerin Ortadoğu'daki hareket alanlarını engellemek istedi. Böyle bir plan için Türkiye'ye ihtiyacı vardı. Bundan dolayı 1942 yılının başlarında bir kere daha Türkiye'nin Almanya'nın yanında savaşa girmesi karşılığında (Gizli Belgeler, 1968, s.59-63) Boğazların savunması için önemli olan ve işgalleri altında bulunan Ege Adalarından bazılarının verebileceklerini söylemişlerdi (Hayta, 1996, s.826). Ancak Türkiye, bu tür önerilere hiçbir şekilde sıcak bakmamıştı (Gizli Belgeler, 1968, s.63).

Benzer bir öneri Nisan 1941'de Almanya'nın Ege'deki bazı adaları işgal etmesi üzerine İngiltere tarafından yapılmış ve Türkiye'nin Almanya ile bir ittifak antlaşması yapması ihtimalinin önüne geçmek için bazı adaların Yunanistan'ın da onayının alınması şartıyla Türkiye'ye bırakılması önerilmişti (Barutçu, 1977. s.183- 184). Türkiye, bu öneriyi Dışişleri Bakanı Şükrü Saraçoğlu vasıtasıyla 30 Nisan 1941'de Almanya'ya iletmiş ve güvenliği açısından önem arz eden bazı adaları geçici olarak kontrol etmek istediğini bildirmişti. Ancak Almanya'nın 11 Mayıs'ta adaları işgal etmesi üzerine İngilizlerin önerisinin bir anlamı kalmamıştı (Koçak, 1986, s.562563).

On iki Ada ile Bulgaristan ve Suriye'deki bazı toprakların Türkiye'ye bırakılması konusunda Rusya'nın görüşleri de dikkat çekicidir. Stalin, 2225 Ocak 1941'de Moskova'da İngiltere Dışişleri Bakanı Eden'le yaptığı görüşmede, Avrupa'nın geleceği ile ilgili düşüncelerini açklarken Türkiye'nin gelecekteki sınırları üzerinde de durmuş ve savaştan sonra Türkiye'ye On iki Ada'nın yanı sıra Bulgaristan'ın Güneyinde ve Suriye'nin Kuzeyinden bazı toprakların verilmesi gerektiğini belirtmiş ve Eden'e söylediklerini aynen Türkiye'ye bildirilmişti (Aydemir, 2011, s. 194- 195; Burçak, 1983, s.90; Arcayürek, 1987, s.158- 159). Sovyet- İngiliz görüşmelerinden sonra verilen yemekte de Stalin, sözü yine Türkiye'ye getirmiş ve

10- Alman Dışişleri Bakanı Ribbentop'tan Papen'e 19 Mayıs 1941'de çekilen telgraf (Gizli Belgeler, 1968, s.20-22; Türkiye'nin Dış Politikasında 50. Yıl, ty. s104; Koçak, 1986, s.275) 
resmî olmayan konuşmada, Almanya'nın doğuya ilerlemesini önlemek için Türkiye'nin bir tampon bölge olarak savaş dışı durumunun önemine değinmişti. Türkiye'nin o andaki konumunun İngiliz- Sovyet ortak çıkarlarına yardımcı olacağını belirttikten sonra, Türk Hükümetinin tarafsızlık politikasını güçlendirmek için Türkiye'ye bazı toprak önerilerinde bulunulması gerektiği ifadesini yenilemişti (Arcayürek, 1987,s.59).

Cumhurbaşkanı İnönü, Türkiye'ye yapılan bu tür önerilere temkinli yaklaşmayı tercih etmişti. İngiltere Dışişleri Bakanı Eden, Stalin ile yaptığ 1 görüşmeyi İnönü'ye aktarınca "neyin bedeli" diye sormuş ve "tarafsızlı̆̆ın bedeli" cevabını almıştı. Ancak İnönü savaş zamanında yapılan bu tür önerileri "savaş zamanının gelip geçici hırslandırmaları" olarak görmüştü (Aydemir, 2011, s.195).

1943 yılının ikinci yarısına gelindiğinde savaşın gidişatı belirginleşmeye başladı. İtalya'nın Avrupa'da yenilmesi Mussolini'nin istifa etmesine sebep olmuştu. Yerine geçen Mareşal Badoglio ${ }^{11}$ Mussolini'yi tutuklatıp partisini de kapattırmış, 3 Eylül 1943'te de müttefiklerle mütareke imzalayarak savaştan çekilmişti. 13 maddelik mütarekenin 6. maddesine göre Askerî harekât üssü olarak veya Müttefiklerin lüzum göreceği diğer amaçlar için kullanılmak üzere Korsika ile bütün İtalyan arazisini ve işgali altındaki adaları derhal teslim etmeyi kabul etti (Hayta, 1996, s., 827).

İtalya'nın mütareke imzalamasından kısa bir süre sonra Almanya, Türkiye'ye adalar konusunda yeni bir öneride bulundu. Ankara'daki Alman İstihbarat Şefi tarafından Milli istihbarat Reisi Naci Perkel'e, iletilen öneri şu şekilde idi;

"Sefirimiz VonPapen Bana şunları söyledi. "karargâh-i umumiden bir telgraf aldım. Bu telgrafta Adaları Türklere teslim etmek istiyoruz. Kendileri ile konuş ve teklifimizi kabul edip etmeyeceklerini öğrenerek bize bildir" deniyordu. Türklerin bu şartlar altında adaları teslim almayacaklarından emin olduğum için kendiliğimden böyle bir teklifin yapılmasının iyi olmayacağını yazdıktan sonra bu mütalaama rağmen teklifi yapmamın lazım olup olmadığını sordum. Bir iki gün içinde Berlin'den bu teklifin behemehâl yapılması için emir gelecek. Git Naci Perkel'le konuş. Alacă̆ın cevabi bana getir"12.

11 - 1940 yııında Mussolini tarafından Genelkurmay Başkanlığı görevinden alınmıştı.

12- 25- 26 Eylül 1943 tarihli belge. Başbakanlık Cumhuriyet Arşivi BCA.030.01.40.240.19.1 
Milli istihbarat Reisi Naci Perkel, Almanlardan aldığı bilgiyi Başbakan Şükrü Saraçoğlu'na iletti. Saraçoğlu, konuyu Cumhurbaşkanına ileteceği zaman Cumhurbaşkanı tarafından teklif karşısında kendisine yönelteceği muhtemel soruları dikkate alarak Perkel'e, "İstihbarat Şefini akşam kabul ederek şu soruları yöneltip cevapların almaya çalış" dedi. Alman İstihbarat Şefine sorularak cevabı alınmaya çalışılacak sorular şu şekildeydi:

“Teklifinizi oldu ğu gibi Başvekile götürecek olursam Başvekilim Bana Almalarn bu adaları teslimden maksatları nedir? Adalar kelimesinin manası neleri ihtiva eder? Bu teslimde birtakım şartlar olacak mıdır? Bu adalarn teslim aldıktan sonra Türkiye istediği gibi hareket edebilecek midir? Bu adalarn mesela Ingiltere'ye teslim edebilecek midir? Gibi suallere maruz kalacağımdan emin olduğum için evvel emirde bu gibi noktalar hakkında tenvirimin zaruretini duydum dersiniz. Alacağınız cevapları bana getiriniz dedim"13.

Almanlardan alınan bilgiler Reisicumhur Umumi Kâtibi Kemal Gedeleç tarafından o sırada Kars'ta incelemelerde bulunan Cumhurbaşkanı İsmet İnönü'ye iletildi. İnönü'den 26 Eylül 1943'te alınan cevap şu şekildeydi: "Düşündü̈̆̈̈nüz doğrudur. Adalar kayıtsız ve şartsız kullanmak üzere alabiliriz. Yoksa bu yüzden Ingilizlerle ve Yunanllarla ihtilafa giremeyiz. Kars'tan Selamlar

\section{İsmet İnönü"14.}

Almanya önerisinin tartışıldığ sırada İngiltere de Türkiye'yi kendi saflarında savaşa sokabilmenin mücadelesini veriyordu. Almanya'nın İstanköy'ü işgal etmesinden sonra önce Ekim 1944'te Churchill, İsmet İnönü ile yaptığ1 görüşmede (Deringil, 1994, s.247) ardından da Kahire'de 5 ve 6 Kasım'da İngiliz Dışişleri Bakanı Eden ile Numan Menemencioğlu arasında yapılan görüşmede Türkiye'nin savaşa girmesi için israr etmişler ve en azında Güneybatı Anadolu'daki hava alanlarını açmasını istemişlerdi (Glasneck, ty., s.145- 147; Arcayürek, 1987, s.199). Bu taleplere Türk Hükümeti 15 Kasım'da cevap vererek savaşa girme talebini Türkiye'nin savaş için yeterli oranda teçhizata sahip olmadığı; hava alanlarının açılması talebini de, Almanya ile meydana gelecek savaş durumu dolayısıyla kabul

\footnotetext{
13 Şükrü Saraçoğlu tarafından Inönü'ye iletilen 25 Eylül 1943 tarihli belge. BCA.030.01.40.240.19.2

14- 26 Eylül 1943 tarihli belge, BCA 030.01.40.240.19.3
} 
etmedi (Glasneck, ty, s. 248). ${ }^{15}$ Bu karar Türk- İngiliz ilişkilerinin gerilmesine sebep oldu. Bazı İngiliz devlet adamları Türkiye ile her türlü ilişkinin kesilmesini bile dile getirdiler. Ancak daha uzun vadeli düşünen İngiliz devlet adamları savaş sonrasında İngiltere'nin bağımsız bir Türkiye'ye ihtiyacı olacağı kanaatindeydiler. Bu kanaatte olanlardan biri olan İngiliz Dışişleri Bakanı Eden, İngiliz- Türk dostluğunu, İngiltere'nin Balkanlarda ağırlı̆̆ını koyabilmesi için zorunlu görüyordu (Deringil, 1994, s.245- 246).

1944 yazına gelindiği zaman Almanya'nın da savaşı kaybedeceği büyük oranda anlaşılmıştı. Bu süreçte Türkiye, bu kez İngiltere'nin Almanya ile siyasi ve iktisadi münasebetlerinin kesilmesi yolunda yaptığı öneriyi, İngiltere ile 19 İkinci teşrin 1939 tarihinde yapılan anlaşmaya uygun olduğunu belirterek kabul etti. Bu gelişmeden sonra Almanya, Türkiye'nin Müttefik Devletlerin yanında savaşa katılma ihtimalinin oluştuğunu düşünerek buna engel olmak için baskılara başladı. Hatta Türkiye'ye gözdağ 1 vermek için, 18 Şubat 1944'te Rodos'taki Türkiye Konsolosluğu binasını bombalamaktan da kaçınmadı (Ülkümen,1 Mart 1974, s.5) ${ }^{16}$. Ancak, savaşın aleyhine dönmesi üzerine, On iki Ada'yı terk etmek zorunda kalacağını anlayınca bir kere daha Türkiye'yi Adaları almaya davet etti. Türkiye, Almanya'nın önerisini İngiltere'ye iletti. İngiltere, Türkiye'ye adaları kendilerinin işgal edeceğini bildirdi (Erkin, 28 Temmuz 1976, s.5). Bu gelişmeler devam ederken Hükümet, TBMM'de verdiği izahat ve yapılan müzakereler sonucunda 2 Ağustos 1944 Çarşamba gününü 3 Ağustos 1944 Perşembe gününe bağlayan gece yarısından itibaren Almanya ile siyasi ve iktisadi münasebetlerini kesilmesi kararını aldı (TBMM Zabit Ceridesi, 2 Ağustos 1944, s.11). Bu kararla birlikte Almanya'nın Türkiye'ye yapmış olduğu öneri de gündemden düşmüştü. Kısa bir süre sonra İngiltere, 1943'ten 1945 yılına kadar Almanların elinde bulunan On iki Ada'y1 1945 yılının ilkbaharında ele geçirerek, 8 Mayıs 1945'ten itibaren kendi askeri yönetimlerini kurdu (BCA. 30.01.40.240.19.6; Turan, 1965 s. 119; Saka, 1974, s. 64; Uçarol, 1995, s. 774- 775).

\footnotetext{
15- Bu gelişmenin ardından Churchill 18 Kasım'da kuvvet komutanlarına şu yazıyı göndermişti: "Türkiye'yi ilkbahar'da savaşa sokmak için aralıksız olarak ciddi bir çaba sarfedilmesi gerekiyor. Gerekli önlemleri alarak Türkiye'yi mutlaka kazanmak zorundayız. Ülkeiyi silahlanma konusunda çok istekli, ordusu iyi durumda. Tek eksikleri özel modern silahlar. Oysa Almanlar Bulgarlara bu silahlardan bol miktarda vererek büyük bir avantaj sağladı" (Denniston, 1998, s.123).

16- Bu bilgiyi Şubat 1944 tarihli gazetelerden doğrulayamadık.
} 
Türkiye, adaların İngilizlerin eline geçmesinden sonra da ihtiyatlı politikasını sürdürmeye devam etti. O sırada Dışişleri Bakanlığı Genel Sekreterliği görevini yürüten Feridun Cemal Erkin, Hükümete müracaat ederek On iki Adanın kaderinin konuşulacağı konferans nezdinde Türkiye'nin herhangi bir talepte bulunup bulunulmayacağını sormuştu. Hükümet, kendi içerisinde konuyu tartıştı. Sovyet Rusya'nın Boğazlarla ilgili tehditlerini de dikkate alarak Erkin'e, "Savaşa katılmadığımız için ganimetlerinden pay almak hakkını kendimizde görmüyoruz, hiçbir teşebbüs yapılmasın" talimatını verdi (Erkin, 1987, s.488).

Feridun Cemal Erkin, Hükümetin kararından eza duyduğunu belirtmekle beraber sorumlu bir devlet adamı olarak talimatlara uyduğunu belirtir. Bununla birlikte resmi işler görüşüldükten sonra İngiliz ve Amerikan Büyükelçilerine

“On iki ada 400 yıl Türk bayrağı altında yaşamıştır. Camileri, evleri, çeşmeleri ile adalar Türk vasfinı taşır. Adaların bazıları Karasularımıza o kadar yakındir ki sabah horoz öttü̈̆̈̈ zaman sesi bizim sahillerimizden işitilir. Simdi konferansin bu adalar Yunanistan'a vereceğini öğreniyoruz. Fakat bu Türk topraklarmı yabancıya verirseniz Türk milleti kararınız hazmedemez. Türk topraklarına yakın olanları Türkiye'ye verilsin, uzak olanlar da Yunanistan'a verilmesinin uygun olacağını" söyler.

Amerikan elçisi konu hakkında sessiz kalır. Ancak İngiliz elçisi durumu Dışişleri bakanları Ernest Bevin'e yazacağını bildirir. Bevin, kendisine yazılan yazıya şu cevabi vermişti.

"Genel Sekreterin cevabını dikkatle okudum. Kendisinin şu gerçeği bilmesini isterim ki On iki Ada Sovyet ve Amerikan Dışişleri Bakanları arasında sırf ırki esaslara dayanularak varılan mutabakat üzerine Yunanistan'a verilmektedir. Ben şimdi konferansta konuyu tekrar açsam pusuda bekleyen Molotof ${ }^{17}$, firsattan yararlanarak Boğazlar sorununu masaya getirecektir. Bir işi halledelim derken başka bir gaile açmayı doğru bulmuyorum" (Erkin, 1987, s.488- 489).

Adalarla ilgili konu Paris'te İtalya ile barış görüşmelerinin devam ettiği sırada yeniden gündeme geldi. İtalya ile barış görüşmeleri daha başlamadan önce Amerika'daki Yunan lobisi ve On iki Adanın temsilcileri New York'ta Yunanistan ile birleşmek istedikleri doğrultusunda eylemler

\footnotetext{
17- Sovyet Dışişleri Bakanı.
} 
düzenleyip, kulis faaliyetlerini yürütmeye başlamışlardı (Turan, 1965. s.117; Hayta, 1996, s.833).

25 Nisan 1946'da İngiliz, Amerikan, Sovyet ve Fransız Dışişleri Bakanları; Paris'te toplanarak İtalya ile imzalanacak barış antlaşmalarını görüşmeye başladılar. Türkiye'nin temsil edilmediği bu görüşmede ${ }^{18}$, İngiltere'nin önerisiyle, Anlaşmanın 14. maddesinin ilk fikras ${ }^{19}$ kapsamında daha önce İtalyan egemenliğinde olan Meis ve On iki Ada'nın Yunanistan'a verilmesine ${ }^{20}$, ikinci fikra ile de adaların askerden arındırılmış olacağına karar verdiler. Askerden arındırılmanın kapsamı, anlaşmanın 13. maddesi ekinin D fikrasında şu şekilde ifade edilmektedir: "işşbu Antlaşma amacıyla" askerden arındırma (de militarisation) ve "askerden arındirlma" (demilitarise) terimleri ile ülke üzerindeki ve ilgili karasularındaki bütün deniz, kara ya da hava tesisleri ve istihkâmları ile kara, deniz ya da hava yapay engellerinin, silahların, kara, deniz ya da hava birliklerince üslerin kullanılmasının ya da bu birliklerce sürekli ya da geçici olarak kalınmasının, her türlü askeri eğitimin ve savaş malzemesi üretiminin yasaklanması biçiminde anlaşılması gerekmektedir. Bu yasaklama sınırlı sayıda içe yönelik görevleri yerine getirecek ve bir tek kişi tarafından taşınabilen ve kullanılabilen silahlarla donatılmış iç güvenlik personeli ile bunlar için gerekli askeri eğitimi içermemektedir (Pazarc1, 1986, s.25).

Antlaşma metninin yayımlanmasından sonra (Ulus, 29 Temmuz 1946; Yahya, 2 Ağustos 1946) daha önce Rodos, On iki Ada ve Meis'i Yunanistan'a vermek niyetinde olduğunu açılayan İngiltere 31 Mayıs 1947'de adaları Yunan askeri idaresine devretti (BCA. 30.01.40.240.19. 6). Bu suretle 1947 yılında, On iki Ada'nın yönetimi fiilen Yunanistan'ın eline geçti. Yunanlılar ilk etapta On iki Ada askerî valiliği ihdas etti. 11 Şubat 1948'de askeri idare kaldırılarak Meis'i de içine alan On iki Ada genel valiliğini oluşturdu (BCA. 30.01.40.240.19. 6).

\footnotetext{
18- Türkiye'nin Ikinci Dünya Savaşı'nda tarafsız olmasına karşılık Italya ile yapılanve OnikiAda'yı ilgilendiren görüşmelere katılma hakkı vardı. (Saka, 1974, s.64).

19. Kanun ya da anlaşma maddelerinin kendi içlerinde satırbaşlarıyla ayrıldıkları ufak bölümlerden her biri. 20. Italya'dan alınarak Yunanistan'ın egemenliğine bırakılan adalar Astampalya (Astropalia), Rodos (Rhodes), Kalki (Calki), Skarpanto, Kazos (Casso ), Piskopis(Tilos), Misiros (Misyros), Kalimnos (Kalymnos), Lcros, Patmos, Lipsos (Lipso), Sombeki (Simi), Istankoy (Kos) veMeis (Castellorizo) adası ile bunlara bitişik adacıklardan oluşmaktadır. (Denk, 1999, s.87; Turan, 1965, s.119; Tasvir, 22 Şubat 1947, s.3; Ulus, 28 Haziran 1946) Kısa bir sure sonra da anlaşma metninin kararları yayımlandı.
} 


\section{Adalardan Anadolu Sahillerine Sı ğınan Mülteciler}

1940 yılı Mayıs'ında Almanya'nın Fransa'ya saldırısı ve İtalya'nın Almanya yanında yer alması ile savaş Akdeniz' e sıçramıştı. 28 Ekim 1940 tarihinde İtalya Yunanistan'a saldırmış ancak beklemediği bir direnişle karşılaşmıştı. İtalya'nın direnişle karşılaşması, Sovyetler Birliği'ne karşı yapacağı saldırı öncesi güney kanadını güvence altına almak isteyen Almanya'nın 1941 Nisan'ında Yunanistan'a ve Ege Adaları'na karşı harekete geçmesine neden oldu. Almanlar planları dâhilinde 25 Nisan 1941'de Taşoz, Semandirek ve Limni Adaları'nı (Yeni Sabah, 27 Nisan 1941) 5 Mayıs 1941'de de Sakız Adası'nı işgal etti (Akça, 2010, s.2). 20 Mayıs 1941'de ise paraşütçü birliklerinin indirilmesiyle Girit Adasını ele geçirdi (Yeni Sabah, 21 Mayıs 1941). İşte bu tarihten itibaren Adalardan Anadolu'ya mülteci ${ }^{21}$ akını başladı. Devlet, mültecilerin belirlenmesi işlemleri ile kamplara sevk ve kamp düzeni hakkında 1941-1942 yıllarında bazı önlemler aldı. 10 Mart 1942'de mültecilerin kabul edileceği bazı kaza merkezleri tespit edildi. Bu merkezlerde mültecilerin ilk soruşturmaları mülki ve askerî üç kişilik bir heyet tarafından yapılacaktı. İltica, sınırın ve mültecinin durumuna göre ayrıca Milli Emniyet kanalından da geçirildikten sonra askeri mülteciler kamplara gönderilecek; siviller durumlarını gösterir bir tutanakla mahalli mülki makama teslim edilecekti. Toplu ilticalarda, iltica edenler en kısa yoldan ve kimseyle temas ettirilmeden kamplara gönderilecek ve ilk soruşturmaları kamplarda yapılacaktı. Gerekirse Milli Emniyet ve Dâhiliye Vekâletinden memur istenecekti. Sayıları, mültecilerin s1nıra girdiği mahallin en büyük mülki amirine bildirilecekti. Toplu meydana gelen ve asker olduklarından kuşku duyulmayanlar ile toplu olmayan ilticalarda askeri mülteci olduklarını kanıtlayanlar askeri mülteci sayılacaktı. Durumları kuşkulu olan mülteciler ise yapılan soruşturmanın vereceği sonuca göre işleme tabi tutulacaklardı (Yaman, 2003 s.145).

\footnotetext{
21- Mülteci konusu esas olarak I. Dünya Savaşı'ndan sonra uluslararası örgütlerin ve devletlerin dikkatini çekmeye başlamış, konu ile ilgili uluslararası antlaşmalar ve sözleşmeler hazırlanmıştır. Birleşmiş Milleler tanımına göre "Mülteci, siyasi, sosyal, dini, meselelere veya ırk meselelerine dayanan sebeplerle asıl memleketinden kaçmış bulunan kimsedir." Mültecinin geçmişinde bu unsurlardan birisinin bulunması şarttır. Mülteci, ülkesinin himayesinde değildir. Gerektiği zaman başvuracağı bir elçi veya konsolosluk yoktur. (Daver, 1953, s.186, 192-194; Altuğ, 1967, s.5- 6, 8).
} 
Adalardan gelen ilk mültecilerin çoğunluğunu Yunan kökenliler oluşturuyordu. Geldikleri yerler çoğunlukla Muğla, İzmir ve Aydın vilayetlerine bağlı Kuşadası, Bodrum, Çeşme, Marmaris ve Söke ilçeleriydi (BCA, 030.10/55.367.41; BCA，030.10/55.367.45; BCA, 030.10/55.367.44; BCA, 030.10/55.367.48) ${ }^{22}$. Yaptığımız incelemede 1941 Mayıs'ından 1 Mart 1943 tarihine kadar 22.525; 18 Ekim 1943'den 16 Aralık 1943 tarihine kadar 1.755; 27 Aralık 1943'den 17 Şubat 1945 tarihine kadar da, 7.118 kişi olmak üzere toplam, 31.398 Yunanlı sivil mültecinin Batı Anadolu, kısmen de Akdeniz sahillerine iltica ettiği anlaşılmaktadır (Akça, 2010, s. 4- 5; Sarısır, 2010, s.511- 513) ${ }^{23}$. Rumların dışında, savaştan kaçan çok sayıda İtalyan, Alman, İngiliz, Amerikan sivil ve askerlerin olduğu bilinmektedir. Gelenlerin bir kısmı bir süre sonra kendi talepleri ile geldikleri yerlere ya da farklı ülkelere iltica etmek istemişti. Devlet, bunlardan durumları uygun bulunanların başka ülkelere gitmelerine izin vermişti ${ }^{24}$. 1 Mart 1943 tarihinden itibaren ise güvenlik gerekçelerinden dolayı Yunan ve kısmen İtalyan adalarından sahillerimize gelen mültecilerin diş memleketlere gidişleri bir süreliğine durdurulmuştu25. Yaklaşık bir yıl sonra Türkiye'ye sığ1nan mültecilerin kendi istekleri ile yurt dışına çıkışlarına yeniden izin verilmişti. Bu kararın ardından Ege adalarından farklı tarihlerde Türk topraklarına sığınan ve Tefenni ile Isparta'daki kamplara yerleştirilen 3051 İtalyan mülteci, Uluslararası hukuk kuralları çerçevesinde ve kendi arzuları doğrultusunda Suriye hudutlarından yurtdışına gönderilmişti ${ }^{26}$.

Türkiye, savaş sırasında gelen Rumları herhangi bir şarta bağlı olmaksızın kabul etmiş ve haklarında uluslararası şartlara uygun olarak mülteci muamelesi yapmıştır. Mültecilerin ilk gelmeye başladıkları Mayıs 1941 tarihinden itibaren Türk Kızılay Cemiyeti aracılığı ile imkânlar dâhilinde başta beslenme olmak üzere giyim, sağlık vb. gibi ihtiyaçları karşılanmaya

\footnotetext{
22- Belgelerde hangi ilçeye kaç kişinin geldiği görülmektedir.

23- Akça ve Sarısır, gelen mültecileri bir tablo üzerinde geldikleri tarih, yer ve kadın- erkek olarak göstermiştir.

24- Bazı örnekler için bak. (BCA.030.10.55.368.11.) Bu belgedeTefenni ve Isparta'dabulunan 3051 italyan mültcinin kendi istekleri ile Suriye'ye yurt dışı edilmeleri talepleri Başvekalete iletilmektedir (BCA.030. 10. 124.882.4.). 8 Mart 1943 tarihli belgede bu şekilde toplam 22 bin 909 kişinin yurt dışınaya da geldikleri yerlere gönderildikleri ifade edilmektedir. Geldikleri yerlere iade edilmeye çalışılanlarla ilgili bazen beklenmedik kazalar da yaşanabiliyordu. Örn. Yunan AdalarındanÇeşme'ye gelen ve umumi karar mucibince geldikleri adalara iade edilmek 235 mülteci 4 Nisan 1942 tarihindeKaptan Ahmet Gürbüz idaresindeki Ender adındaki bir motorla iade edilirken, motor kayalara çarparak battı. Ancak üçTürk tayfa ile 26 mülteci kurtulabildi. 10 Nisan 1942 tarihlibelge. (BCA.030.10.171.185.22.)

25. 8 Mart 1943 tarihlibelge. (BCA.030. 10. 124.882.4.)

26- (BCA.30.10. 55. 368. 11) Milli Müdafaa Vekâleti Ordu Dairesinin 24 Mart 1944 tarihli yazısı.
} 
çalışılmıştı (Keser, 2009, s.197- 198). Meslek sahibi olanlara ise iş imkânlarının sağlanmasına özen gösterilmişti ${ }^{27}$. Bu uygulama Türkiye Almanya'ya savaş ilan ettikten sonra da devam etmiştir ${ }^{28}$.

Türkiye'nin bu iyi niyetli yaklaşımı savaştan sonraki dönemde yeteri kadar karşılık bulamadı. Başta Girit ve Rodos Adaları olmak üzere adalarda yaşayan Türklere karşı baskı uygulanmaya başlandı. Ellerindeki mallar gasp edilerek göçe zorlandılar (Akşam, 12 Temmuz 1947; Salkım, 17 Temmuz 1964).

\section{Sonuç}

Türkiye İkinci Dünya Savaşı sürecinde On iki Ada ile ilgili Lozan barışını esas aldı. Lozan'da tam olarak netleştirilmediği konuları da İtalya ile yaptığ görüşmeler sonucunda 4 Ocak 1932'de açıklığa kavuşturarak Ankara'da imzalanan antlaşma ile Bodrum Körfezi'ndeki Kara ada ve Meis'e bağlı otuz adacıktan 19'u Türkiye'ye; 11'i ise İtalya'nın hâkimiyetinde bırakılmıştı.

İkinci Dünya Savaşı'nda Türkiye, savaşan devletler arasında tarafsız kalmayı tercih ederek adalar konusunda sahip olduğu konumu muhafaza etmeye çalışmıştı. Bu yüzden başta Almanya olmak üzere İngiltere ve Sovyet Rusya tarafından adaların Türkiye'ye verilebileceği şeklinde yapılan önerileri "kendisini savaşa sokma gayreti" olarak görerek reddetmişti. Buna rağmen Türkiye, bütünü ile kendisini savaşın dışında tutamamış ve özellikle adalardan Anadolu'ya gelen mültecilerle yakından ilgilenmişti. Bu durum Türkiye'nin ciddi güvenlik tedbirlere başvurmasına ve aynı zamanda ekonomik önlemler almasına sebep olmuştur.

Savaşın sonuna yaklaşıldığı dönemde ise Türkiye'nin önceliklerinde önemli değişiklikler oldu.19 Mart 1945'te Ruslar, Türkiye ile 17 Aralık 1925'te imzalamış oldukları ve 7 Kasım 1945'te süresi bitecek olan Dostluk Antlaşmasını, İkinci Dünya Savaşı sırasında meydana gelen değişiklikler yüzünden mevcut şekliyle yenilemeyeceklerini bildirmişlerdi. 7 Haziran

\footnotetext{
27. (BCA.30.10. 122. 882. 12);Sanatkâr mültecilerin Aydın, İzmir ve Nazilli'ye gönderilmelerine dair Sıhhat ve İçtimai Muavenet Bakanlığının 2 Mayıs 1945 tarihli yazısı.

28- Bu konuda Muğla Valiliği tarafından sorulan bir soruya 22 Şubat 1954 tarih ve 1/687 tarihli şifre ile verilen cevapta "Alman işgali altındaki adalardan gelecek mültecilerin evvelce olduğu gibi yurda kabulü Başbakanlığın emir iktizasındadır. Gereğinin yapılması rica olunur" deniyordu. (BCA.030. 10. 117.815.17.) Başbakanlıktan Muğla Valiliğine 14 Mart 1945'te yazılan yazı.
} 
1945 'te ise iki ülke arasındaki anlaşmanın yenilenmesi için herhangi bir saldırı karşısında ortak savunma yapmak üzere Boğazlarda üs verilmesi ve Gürcü ve Ermenilerin talepleri doğrultusunda Kars, Ardahan ve Artvin'in kendilerine birakılması talebinde bulunmuşlardı. Rusların talepleri karşısında Türkiye, önceliğini Batıdan müttefik bularak tehlikeyi önleme gayretine girmişti.

Türkiye, bu kritik dönemde İkinci Dünya Savaşı'ndan sonra yapılan Paris Antlaşmasının adalarla ilgili görüşmelerine katılmayı ve Türkiye'ye çok yakın olan adaların alınması konusunu dile getirmeyi düşünmüştü. Ancak o dönemde Türkiye'nin, Sovyet Rusya ile olan ilişkilerindeki gerginlikten hareketle hem Onlara, Boğazlarla ilgili taleplerini uluslararası alana taşıma fırsatı verebileceği, hem de kendisini müttefiklerinden uzaklaştırabileceği endişesinden dolayı bu fikrinden vazgeçmiş ve "savaşan taraflardan biri olmadığı" gerekçesi ile görüşmelere katılmamayı daha uygun bulmuştu. Bununla birlikte Lozan'da adalarla ilgili alınan kararlar ve İtalya ile yaptığı görüşmeler sonucunda 4 Ocak 1932'de Ankara'da imzalanan antlaşma ile Türkiye'ye bırakılan Bodrum Körfezi'ndeki Kara Ada ve Meis'e bağlı otuz adacıkla ilgili statünün muhafazasını istemişti. Yunanistan'a bırakılacağı ifade edilen On iki Ada'nın da iki ülke arasında barışın geleceği için silahsızlandırılması konusunda ısrarcı olmuştu. Nitekim Paris Antlaşması ile adalar Yunanistan bırakılırken, Türkiye'nin talepleri de yapılan antlaşmanın 14. maddesine konulmuştu.

Buna rağmen ilerleyen yıllarda Türkiye ve Yunanistan'ın NATO'ya girmelerinin ardından Yunanistan, adaların kendisine devredilmesinde rolü olan devletlerden de cesaret alarak NATO şemsiyesi altında adaları kısmen silahlandırdı. Tarihi emelleri doğrultusunda Ege denizini bir Yunan denizi haline getirme mücadelesi vermeye başladı. Bu amaç doğrultusunda, uluslararası antlaşmalardan kaynaklanan yükümlülüklerini ihlâl etmekten çekinmedi. Bu durum iki ülke arasında o zamandan günümüze kadar gelen tartışmaların başlamasına sebep oldu. 


\section{EXTENDED ABSTRACT}

\section{AegeanIslandsDisputeandTurkey: World War II Period \\ Yaşar Semiz- Güngör Toplu \\ Selçuk University}

Aegean islands have become a topic on the agenda with the invasion of Rhodes and the 12 islands by the Italians during the Tripoli War and continued by the occupation of some islands by Greece during the Balkan War. It was partly settled, providing that the Aegean Islands excepting Gökçeada (Imbros) and Bocaada (Tenedos) would be left to Greece on condition that they would demilitarized with the article 12 of the Treaty of Lausanne and that the Rhodes and the Twelve Islands would be left to Italy with its 15th and 16th articles.

The discussion on the islands started again in 1927. The subject matter discussed during this period of time was the rocks around Rhodes and the twelve islands left to Italy. During the debates between Turkey and Italy, Turkey advocated the thesis that islets of Meis were not mentioned in the $15^{\text {th }}$ Article of the Treaty of Lausanne and therefore, if there was no record on contrary to those in the second paragraph of Article 6 of the Treaty of Lausanne, the island and the islets within 3 miles of the territorial waters would have to be left to country having that territorial waters Unlike Turkey, Italy claimed that the expression "islet subject to them" in the Article 15 of the Treaty of Lausanne, $"$

Turkey mentioned its concerns related to twelve islands under the control of Italy before the World War II and during the war years in Germany, Britain and Russia many times. This states uttered that if Turkey would go to war together with them, they could give the island to Turkey.

During the Second World War, Turkey, preferring to remain neutral in the war between states, it tried to maintain the position it had related to the islands. Therefore, it refused their proposals mainly those made by Germany and then Britain and Soviet Russia related to the return of the islands to Turkey by considering these proposals as "efforts for entering it the war". Nevertheless, Turkey could not be able to exclude itself from the war and was closely interested in refugees who came to Anatolia especially from the island. 
This situation has led to Turkey to resort to taking serious security measures and also economic measures.

And during the time towards the end of the war, there have been significant changes in Turkey's priorities. On March 19, 1945, the Russians reported that they would not renew the "Treaty of Friendship" signed with Turkey in December 17, 1925 which would expire on November 7, 1945, due to changes that occurred during the World War II. On June 7, 1945, they requested the bases be given to the Soviets in order to renew the treaty between the two countries and that Kars, Ardahan and Artvin should be left to them in the direction of requests of Georgians and Armenians. Turkey attempted to prevent the danger by finding alliances from the West under the demands of the Russians.

During this critical period of time, Turkey thought to participate in debates of the Treaty of Paris related to Islands which was made after the World War II and to utter receipt of the islands which were very close to Turkey. However, at that time, because of the tension in the relationships of Turkey with the Soviet Russia, Turkey abandoned this idea both due to the concerns of giving them opportunity to bring their demands related to Bosporus into the international area and due to concerns of that that they may detract from its allies, and found it more appropriate not to participate in negotiations with the reason that it was not one of the "parties of war"

However, as a result of decisions taken related to the islands in Lausanne and as a result of debates with Italy, with treaty signed in Ankara in 04.01.1932, Turkey wanted to protect the status concerning Kara Ada in Bodrum Gulf and thirty islets of Meis which were given to it. It also insisted that the twelve islands which would be left to the Greece should be disarmed for the future of peace between two countries. Thus, while the island were left to Greece with the Treaty of Paris, requests of Turkey were added in Article 14 of the Treaty concluded.

Nevertheless, in the advancing years followed by the entry of Turkey and Greece into NATO, Greece partially armed the islands under the umbrella of NATO by taking encouragement from the states which played a role in the transfer $\mathrm{f}$ islands. In the direction of his historical ambitions, it started struggle to turn the Aegean Sea into a Greek sea. In accordance with this purpose, it did not hesitate to breach its obligations under international treaties. This situation caused the generation of discussions between two countries until today. 


\section{Kaynakça / References}

\section{Arşiv Kaynakları}

Başbakanlık Cumhuriyet Arşivi (BCA)

BCA.030.01.40.240.19.1

BCA.030.01.40.240.19.2

BCA.030.01.40.240.19.3

BCA. 30.01.40.240.19.6.

BCA. 030.10/55.367.41

BCA. 030.10/55.367.44

BCA. 030.10/55.367.45

BCA. 030.10/55.367.48

BCA.030.10.55.368.11

BCA.030.10.171.185.22

BCA.030. 10. 124.882.4

BCA.30.10. 122. 882. 12

BCA.030. 10. 117.815.17

TBMM Zabit Ceridesi, Devre 4, C. 12, İçtima 2, 21. inikat, 7 Ocak 1933.

TBMM Zabit Ceridesi, Devre 4, C. 12, İçtima 2, 24. inikat, 14 Ocak 1933.

TBMM Zabit Ceridesi, Devre 6, C. 2, İçtima F, 11. İnikat, 12 Mayıs 1939.

TBMM Zabit Ceridesi, Devre 7, C. 13, İçtima 1, 2 Ağustos 1944.

Düstur, Üçüncü Tertip, C.5, 11 Ağustos 1339- 19 Teşrinievvel 1340, Necmi İstiklal Matbaası, İstanbul 1931, madde 12, s. 25. Madde 15.

\section{Gazeteler}

Akşam, 12 Temmuz 1947.

Tasvir, 22 Şubat 1947.

T.C. Resmi Gazete 25 Ocak (Kanun-i sanı) 1933, Sayı 2313.

Ulus, 28 Haziran 1946.

Ulus, 29 Temmuz 1946.

Yeni Sabah, 27 Nisan 1941.

Yeni Sabah, 21 Mayıs 1941.

Akça, B. (2010). II. Dünya Savaşı yıllarında Ege Adalarından Batı Anadolu sahillerine sı̆̆ınan mülteciler meselesi, Muğla Üniversitesi Sosyal Bilimler Enstitüsü Dergisi, 24, 1- 11

Altuğ, Y. (1967). Devletler hususi hukuku bakımından mülteciler. İstanbul Üniversitesi Hukuk Fakültesi Yayını: Sermet Matbaası.

Arcayürek, C. (1987). Şeytan üçgeninde Türkiye. İstanbul: Bilgi yay. 
Aydemir, Ş. S. (2011). İkinci adam (1938- 1950). (Cilt No:2), İstanbul: Remzi Kitabevi.

Barutçu, F. A. (1997).Siyasi anılar. (1939- 1954). İstanbul: Milliyet yay.

Burçak, R. S. (1983). Moskova görüşmeleri ve dış politikamız üzerindeki tesirleri. Ankara: Gazi Üniversitesi Basın Yayın Yüksekokulu Yay.

Daver, B. (1953).İnsan hakları ve mülteciler meselesi, Ankara Üniversitesi Siyasal Bilgiler Fakültesi Dergisi, 8(1), 185- 199.

Denk, E. (1999). Egemenliği tartışmalı adalar-karşılaştırmalı bir çalışma. Ankara: Mülkiyeliler Birliği Vakfı Yay.

Denniston, R. (1998). Churchill'in gizli savaşı (1942- 1944).(S.GürtuncaÇev.), İstanbul: Sabah Kitapları.

Deringil, S. (1994). Denge oyunu- Ikinci Dünya Savaşında Türkiye’nin dış politikası. İstanbul: Tarih Vakfı Yurt yay.

Erden, A. F.(1999).İsmet İnönü. Ankara: Bilgi yay.

Erkin, F. C. (Temmuz 28, 1976). On iki Ada'yı Yunanistan'a kim ve nasıl verdi?,(Tefrika 1), Milliyet.

Feridun C. E. (1987). Dışişlerinde 34 yıl, (Cilt No:2), Ankara: Türk Tarih Kurumu Yay.

Glasneck, L. (T.y). Türkiye'de Faşist Alman propagandası. (A. GelenÇev.), Ankara: Onur Yay.

Goloğlu, M. (1974). Milli şef dönemi (1939-1945). Ankara: Kalite Matbaası.

Hayta, N. (Kasım 1996).İkinci dünya savaşı yıllarında Ege Adaları sorunu, Atatürk Araştırma Merkezi Dergisi, 12(36), 817-848,

İkinci Dünya Savaşında Gizli Belgeler- Almanya'nın Türkiye Politikası (19411943), (1968). İstanbul: May yay.

Karabekir, K. (1995). Ankara'da savaş rüzgârları. İstanbul: Emre yay.

Ulvi K. (2009).Arşiv belgeleri 1şı̆̆ında İkinci dünya savaşı sürecinde Türkiye'de Mülteciler ve Esirler Sorunu, Çă̆daş Türkiye Tarihi Araştırmaları Dergisi, 8(18-19), 185- 208.

Koçak, C. (1986). Türkiye'de milli şef dönemi. İstanbul: İletişim yay.

Kurtcephe, İ. (1991). Rodos ve 12 Adanın İtalyanlar tarafındanişgali. İçinde (s.201216), Ankara: OTAM

Pazarcı, H. (1986). Doğu Ege Adalarının askerden arındırılmış statüsü. Ankara: A.Ü. Siyasal Bilgiler Fakültesi Basın Yayın Yüksekokulu yay.

Saka, M. (1974). Ege Denizinde Türk hakları. İstanbul:Dergâh yay.

Salkım, A. (17 Temmuz 1964). Nasıl baskı yapıyorlar- Gasp edilen Türk Emlaki, Cumhuriyet. 
Sarısır, S. (2010). II. Dünya Savaşı Yıllarında Anadolu sahillerine sığınan Yunanlı sivil mülteciler, Konya: S.Ü. Türkiyat Araştırmaları Dergisi, 27, 505- 527,

Semiz, Y. ve Akgün, B. (2007). Dostluktan krize, ikinci dünya savaşı sürecinde Türk- Rus İlişkileri, Konya: Selçuk Üniversitesi İIBF Sosyal ve Ekonomik Araştırmalar Dergisi,8(14), 239- 270,

Soysal, İ. (1983). Türkiye'nin siyasal antlaşmaları(1920- 1945), (Cilt No:1), Ankara: Türk Tarih Kurumu Yay.

Turan, Ş. (1965). Rodos ve On iki Ada'nın Türk hâkimiyetinden çıkışı.Belleten, 29(113), 77- 119.

Türkiye'nin Dış Politikasında 50. Yıl İkinci Dünya Savaşı Yılları, (1939- 1946).

(T.y). Ankara: T.C. Dişişleri Bakanlığı yay.

Uçarol, R. (1995). Siyası tarih(1789- 1994). İstanbul: Filiz Kitabevi.

Ülkümen, S. (1 Mart 1974). İkinci Dünya Savaşı'nın bilinmeyen bir yönü- Almanlar Rodos konsolosluğumuzu bombalamışlardı, Milliyet.

Wells, S. (T.y). Karar zamanı. (Çev. Z. Sertel), İstanbul, Lütfi Kitabevi. Yahya, A. (2 Ağustos 1946). İtalyan barış şartlarının ana hatları. Tasvir.

Yaman, A. E. (2003). II. Dünya Savaşında Türkiye' de askeri mülteciler ve gözaltı kampları (1941-1942), Ankara Üniversitesi Dil ve Tarih- Coğrafya Fakültesi Tarih Bölümü Tarih Araştırmaları Dergisi, 21(33), s. 144- 166.

\section{Ekler}

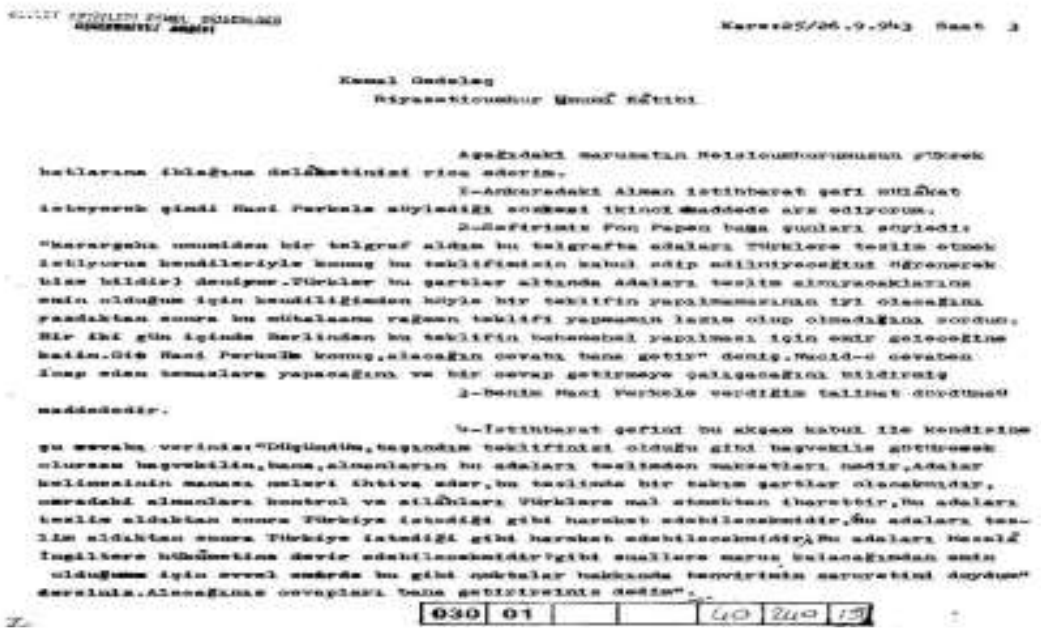


Ege Adaları Tartışması ve Türkiye: II. Dünya Savaşı Süreci

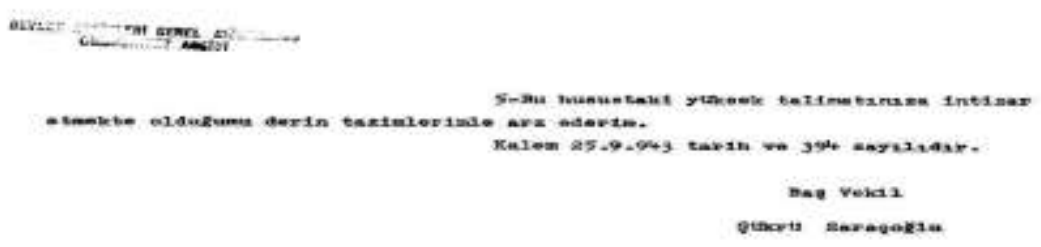

\begin{tabular}{|l|l|l|l|l|l|}
\hline 030 & 01 & & | & (40) 240 & 19 \\
\hline
\end{tabular}

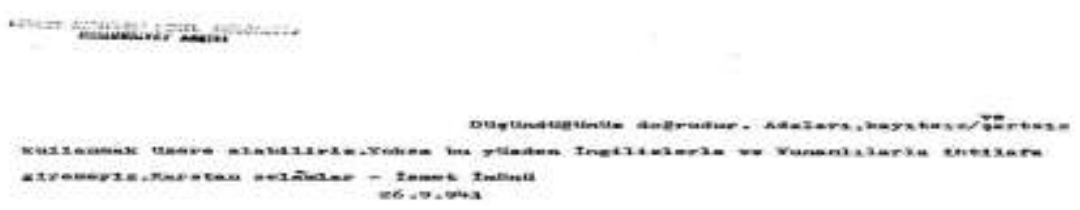

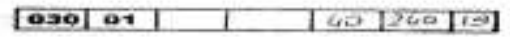




\section{T. C.}

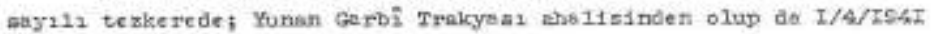

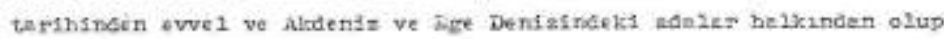

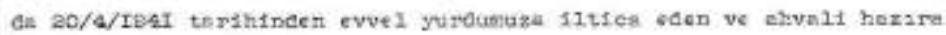

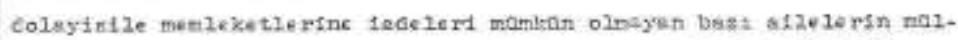

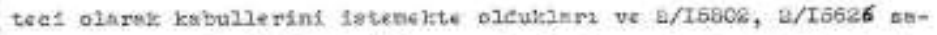

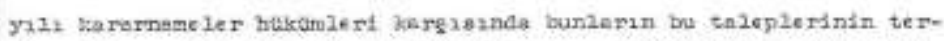

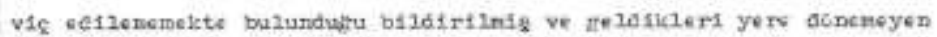

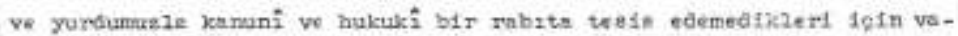

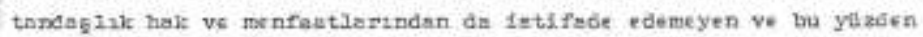

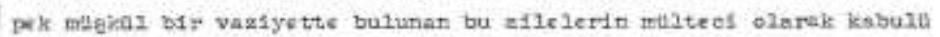
ile vazlyetzerinin tagbit ve teyini bir sok betciman faydeli olacajt

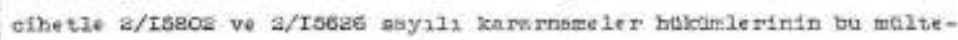

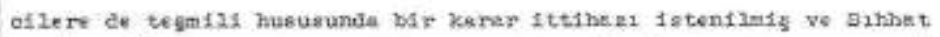

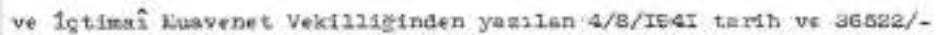

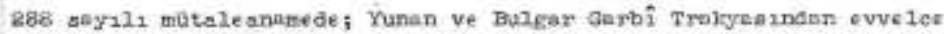
Taridyeye gelmig ve moltecl muamelesine tebi tutulmnarg olan ve nemleketlerine fadelert de ncmldon bulummadigi enlagilien Furklerin vazi-

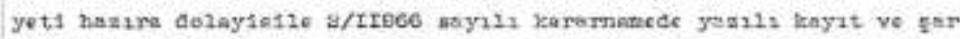

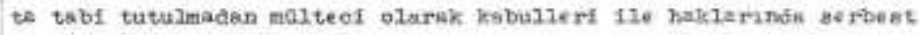

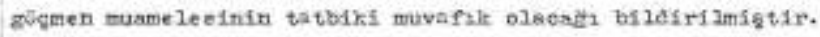

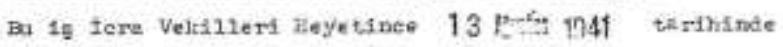

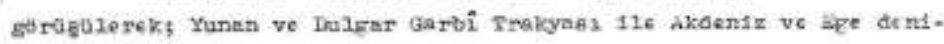
alndekd adelar abaliainden olup ca s/Iseos, e/LS686 sayil kerama-

otc 18 on $0 2 \quad 9 6 \longdiv { 7 2 }, 3$



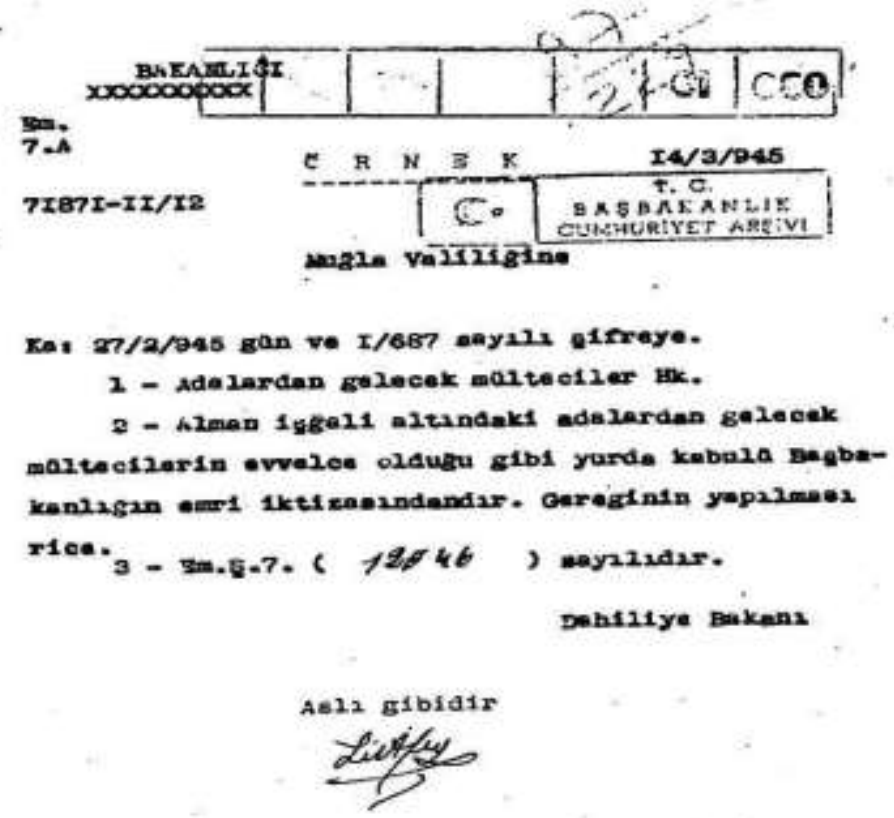

\begin{tabular}{|l|l|l|l|l|l|}
\hline 030 & 10 & & & 117 & 815 \\
\hline
\end{tabular}

\section{KaynakçaBilgisi / Citation Information}

Semiz, Y. ve Toplu, G. (2019). Ege adaları tartışması ve Türkiye: II. dünya savaşı süreci. OPUS-Uluslararası Toplum Araştırmaları Dergisi, 13(19), 2381-2403. DOI: 10.26466/opus.568459 